\title{
'Time is flying': Lyrical and Historical Time in the Poetry of Percy Bysshe Shelley
}

\section{'Zaman Uçuyor’: Percy Bysshe Shelley’nin Şiirlerinde Lirik ve Tarihsel Zaman}

\section{Cian DUFFY*}

\begin{abstract}
The quotation in the title of this essay is taken from a manuscript fragment composed by the English Romantic poet Percy Bysshe Shelley a few weeks before his death in July 1822. As a reflection on the calamities which time can unleash, this fragment might seem eerily prescient. But as this essay shows, Shelley's fragment - together with his contemporary poem 'The Triumph of Life', left unfinished at his death - is only the latest instance of a sustained interrogation, in Shelley's poetry, of the nature and implications of time. Shelley's major political works often headline confidence in a linear, progressive interpretation of historical progress, with natural and social processes cooperating to produce meliorative change over long periods of time. Beneath this prima facie confidence, however, these same works often betray an anxiety that time might rather be an unbroken and unbreakable, catastrophic cycle of creation and destruction. My essay traces this tension in a selection of Shelley's political and lyrical verse and links it to key contemporary debates in political theory and natural philosophy. Studying Shelley's engagement with time sheds new light not only on Shelley's thought but also on the ways in which Romantic poetry could embody this key facet of human experience.
\end{abstract}

Keywords: Shelley, time, lyricism

Öz

Bu makalenin başlığındaki alıntı, İngiliz Romantik şair Percy Bysshe Shelley’nin Temmuz 1822'deki ölümünden birkaç hafta önce yazdığı bir fragmandan alınmıştır. Zamanın sebep olabileceği felaketler üzerine bir düşünce olarak bu fragmana ürkütücü bir öngörü olarak bakılabilir. Ancak bu makalenin de ortaya koyduğu gibi, Shelley’nin bu fragmanı -kendisinin ölümüyle yarım kalmış aynı dönem şiiri 'Yaşamın Zaferi' ile birlikte- Shelley’nin şiirlerinde zamanın doğası ve manası üzerine hep sürdürdüğü sorgulamaların sadece en son örneğidir. Shelley'nin başlıca politik eserleri genellikle düzçizgisel, ilerlemeci bir tarih yorumunu doğal ve toplumsal süreçlerin katkısını da hesaba katarak uzun yıllar içinde iyiye doğru evrilen bir tarihsel bakış açısıyla ele alır. Ancak ilk bakışta öyle görünse de, aynı eserler genellikle zamanın kırılmamış ve kırılamaz bir yaratım ve yıkım döngüsü olabileceği endişesini de gizleyemez. Bu çalışma, bahsi geçen gerilimin izini, Shelley'nin bazı politik ve lirik şiirleri üzerinden sürüp, bu gerilimi günümüz politik kuramı ve doğa felsefesindeki kilit tartışmalara bağlamayı hedeflemektedir. Shelley'nin zamanla ilişkisini çalışmak yalnızca Shelley'nin düşüncelerine değil, aynı zamanda insanlık deneyiminin bu temel alanına Romantik şiirin nasıl şekil verdiğini kavrama yollarına da 1şı1k tutacaktır.

Keywords: Shelley, Zaman, Lirizm.

\section{Introduction}

In the weeks before his death on 8 July 1822, the English Romantic poet Percy Bysshe Shelley (1792-1822), who had lived in Italy since the spring of 1818, was working on what would prove to be his last major poem: 'The Triumph of Life'. ' Left unfinished at Shelley's death, the extant draft of 'The Triumph of Life' encompasses some 550 heavily-worked lines as well as four discarded openings and at least two apocryphal passages, all composed in terza rima, the interlocking Italianate verse form pioneered by Dante Aligheri (1265-1321) in his Divina Commedia (1320) and by Francesco Petrarca (1304-74) in his Trionfi (1374) - both significant hypotexts for Shelley's poem. ${ }^{2}$ The assortment of loose sheets of paper on which

\footnotetext{
* Prof. Dr., Lund University, Center for Languages and Literature, cian.duffy@englund.lu.se

1 'The Triumph of Life' has received substantial attention from scholars and editors of Shelley's work, my reliance on which it would be difficult to enumerate in the following pages. Seminal studies to which all commentators on the poem are greatly indebted include: Matthews, 1961; Matthews, 1962; Reiman, 196; and Reiman, 1965. For my own earlier work on the poem, see Duffy, 2006, p. 187-201.

${ }^{2}$ Selections from the discarded openings and apocrypha were first published in Matthews (1960a, 1960b); full texts were first published in Reiman (1965). Shelley's draft of ToL now forms part of the Abinger deposit at the Bodleian Library, Oxford, and is catalogued as Bodleian MS. Shelley adds. c. 4, folios 18-58.
} 
Shelley drafted 'The Triumph of Life' also contain a number of shorter pieces. One of these is the relatively well-known lyric 'To Jane' (beginning 'The keen stars were twinkling'), in which Shelley recalls an evening sailing off the coast of Viareggio in his boat, the Don Juan, with Mary Shelley (1797-1851) and their friends Edward Ellerker Williams (1793-1822) and his wife Jane (1798-1884), to whom Shelley was intensely attracted. ${ }^{3}$ Another is the far lessfamiliar, untitled lyric fragment beginning 'Time is flying', on Bodleian MS. Shelley adds. c. 4, folio 37 reverso - which, to the best of my knowledge, has yet to be published in an edition of Shelley's poetry:

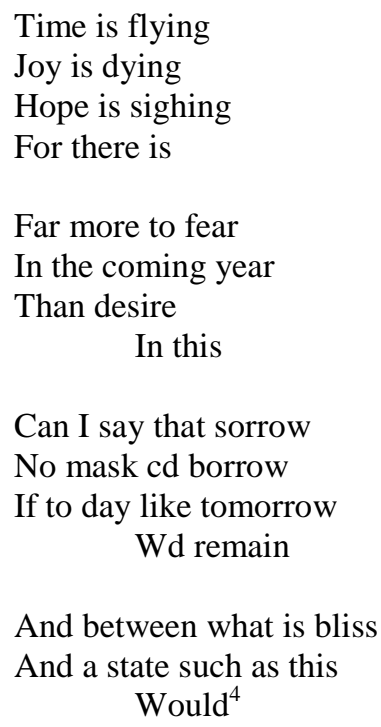

These lines represent the passage of time as a process of loss and the fragment breaks off at the exact moment when Shelley begins to reflect on whether or not such loss is inevitable and irreversible. This was a problem very much on Shelley's mind in June 1822. In his aforementioned letter of 18 June, for example, in which he describes an evening sailing with the Williamses, Shelley concludes by noting that 'if the past and the future could be obliterated, the present moment would content me so well that I could say with Faust to the passing moment, "Remain, thou, thou art so beautiful"" (Shelley, 1964 2, pp. 435-6). ${ }^{5}$ In the very last lyric on which Shelley worked before his death,'Lines written in the Bay of Lerici', which recalls an evening spent alone with Jane Williams, we can see the same dynamic. The unfinished poem valorises the intensity of a moment of pleasure - 'I lived alone/ In the time which is our own; / The past and future were forgot/ As they had been, and would be, not' (lines 2032) - and then breaks down, like the fragment 'Time is flying', when Shelley tries to find some way to account for or to resolve the seemingly inescapable collapse of 'pleasure' into 'regret' (lines 54-7). ${ }^{6}$ Shelley's draft of 'The Triumph of Life', too, comes to an end shortly after the narrator poses the question 'What is life'? (line 544) in an apparent attempt to come to terms with what appears to be the inescapable collapse of almost every human ideal and achievement, personal and political alike, in the face of the passing of time. Would Shelley have been able to resolve any of these unfinished drafts, and with them the problem of time, if his own life had not come to an end on 8 July 1822 ?

\footnotetext{
${ }^{3}$ Shelley describes just such an evening in a letter to John Gisborne of 18 June 1822, which is closely contemporary with 'To Jane'. See Shelley 1964 2: 435-6. On Shelley's feelings for Jane Williams and the poems they inspired, see Matthews, 1961; Reiman, 1963; Reiman, 1965; and Duffy, 2015

${ }^{4}$ The fragment has previously been published in Shelley-Rolls and Ingpen, 1934, p. 71; Rogers, 1956, p. 288; and Reiman, 1965, p. 246-7.

${ }^{5}$ Cf. Goethe (1808) iv 1699-1705.

${ }^{6}$ Unless otherwise indicated, all quotations from Shelley's poetry and prose are taken from Shelley 2017.
} 
This essay looks at how Shelley engages with time and loss in a selection of his private lyrics and published political verse. It describes a contrast between a more pessimistic understanding of time in the lyrics and Shelley's attempts to forge a progressive understanding of historical process in his political works, but also notes that even Shelley's greatest narratives of successful revolution are not free of doubts, do not wholly trust in time. The essay seeks in addition to situate Shelley's engagement with time in the context of wider, contemporary debates about the relationship between natural history and human history. It also considers what the temporality of Shelley's verse might add to our understanding of the poetics of what M. H. Abrams (1965) first described as 'the Greater Romantic lyric'.

\section{Shelley and Lyrical Time}

The representation of loss and the lyrical mode are closely aligned in Shelley's oeuvre, and especially so in his later verse. In fact, almost every lyric which Shelley wrote or began to write in the last year of his life focuses on the losses wrought by time. Some opening phrases alone should be sufficient to make this point: 'Ah me my heart is bare/ Like a winter bough'; 'Far, far away, o Ye/ Halcyons of Memory'; 'Now the last day of many days/ Is fled'; 'Swifter far than summer's flight/ [...] Art thou come and gone'; 'The flower that smiles today/ Tomorrow dies'; 'The warm sun is failing, the bleak wind is wailing'; 'The serpent is shut out from paradise'; 'When the lamp is shattered/ The light in the dust lies dead'. And there are many others. Loss is ubiquitous in Shelley's later lyrics.

One would not, of course, have to enquire very far into Shelley's personal circumstances in 1821-22 in order to understand where such a preoccupation with loss might originate. Shelley's perceived lack of success as an author; his indifferent health; his sense of being overshadowed by his friend, Lord Byron (1788-1824); the death of all but one of his children with Mary; Mary's depression and the crisis in their marriage; the frustration of his unrequited desire for Jane Williams; his despair over the increasingly repressive political situation in Britain and the widespread ascendancy of reactionary politics across Europe - all this goes a very long way indeed towards explaining why Shelley, in a letter to Claire Clairmont (17981879 ) of 11 December 1821, could write, accepting her earlier identification of him with an ailing plant:

The Exotic as you please to call me droops in this frost - a frost both moral \& physical - a solitude of the heart [...] I am employed in nothing - I read - but I have no spirits for serious composition - I have no confidence and to write \& [for in] solitude or put forth thoughts without sympathy is unprofitable vanity (Shelley 1964 2: 367-8).

By addressing this kind of existential 'frost' in lyric verse, Shelley was, of course, following a track already trodden by many of his contemporary Romantic poets, including William Wordsworth (1750-1850), whose 'Lines Written a Few Miles above Tintern Abbey' (1798), sets out to acknowledge and then to redress the losses wrought by time: 'Five years have passed; five summers, with the length/ Of five long winters!' (lines 1-2). In his seminal study of this genre, 'Structure and style in the Greater Romantic Lyric', M. H. Abrams, one of the founding fathers of the academic study of British Romanticism in the twentieth century, outlines what he sees as a recurrent, formal and thematic pattern:

The speaker begins with a description of the landscape; an aspect or change of aspect in the landscape
evokes a varied but integral process of memory, thought, anticipation, and feeling which remains close-
ly intervolved with the outer scene. In the course of this meditation the lyric speaker achieves an in-
sight, faces up to a tragic loss, comes to a moral decision, or resolves an emotional problem. Often the
poem rounds upon itself to end where it began, at the outer scene, but with an altered mood and deep-
ened understanding which is the result of the intervening meditation (Abrams, 1965, pp. 527-528).

The key point that Abrams makes here is to note the 'altered mood and deepened understanding' with which the Romantic lyric typically concludes, the result of the 'intervening medita- 
tion' conducted over the course of the poem itself. Often in the Romantic lyric, this involves the speaker redressing the loss experienced before the poem begins through the temporal process of the poem itself. The Romantic lyric is a working out in verse time of the problems of experiential time. Hence Wordsworth, for example, finds what he describes in 'Tintern Abbey' as 'abundant recompense' (line 90) for the passing of time in what he calls, in his 'Ode. Intimations of Immortality' (1807), the 'years that bring the philosophic mind' (line 191).

But no such resolution is possible for Shelley, at least not in those lyrics written in the last year of his life: those which he finished reach no solution to the problem of loss in time and those which he left unfinished break down at the precise moment when he tries to articulate a solution. I want to examine in more detail, now, how it is that Shelley defines the problem of time in his lyrics and why it is that the lyric mode offers no solution to that problem. But in order to do this adequately, we need, first, to understand the extent to which the lyrics which Shelley composed in the last year of his life are, in fact, the culmination of a much more sustained and politically-motivated attempt, on his part, to explore and to narrate time in verse.

\section{Shelley and Revolutionary Time}

Commentators on both sides of the political divide in the so-called Revolution Controversy in England in the 1790s were agreed that the French Revolution signalled a radical break with the past and posed fundamental questions about the nature and the direction of historical time. The conservative thinker Edmund Burke (1729-97), in his Reflections on the Revolution in France (1790), concluded that the Revolution was without precedent: 'all circumstances taken together', he wrote, 'the French revolution is the most astonishing that has hitherto happened in the world' (Burke, 1791a, p. 11). For Burke, any radical break with tradition was dangerous and to be deplored as fundamentally detrimental to the stability of civil society: 'a spirit of innovation', he claims, 'is generally the result of a selfish temper and confined views. People will not look forward to posterity, who never look backward to their ancestors' (Burke, 1791a, pp. 47-8). And hence Burke's often-quoted (then and now) characterisation of the French Revolution as a decisive and disastrous turning point in the cultural history of Europe: 'the age of chivalry is gone', he laments: 'that of sophisters, economists, and calculators, has succeeded; and the glory of Europe is extinguished for ever' (Burke, 1791a, p. 113).

For others, however, the French Revolution represented nothing less than the reinvention of history and the possibilities of historical time. Burke's foremost antagonists, Thomas Paine (1737-1809) and Mary Wollstonecraft (1759-97) both saw the Revolution as the moment when the stultifying influence of aristocratic and religious tradition was broken. Paine, for example, in The Rights of Man (1791), rejected Burke's valorisation of tradition and insisted, instead, on the possibility of revolutionary change, of giving historical time a new shape and direction. 'There never did, there never will, and there never can', Paine writes:

exist a Parliament, or any description of men, or any generation of men, in any country, possessed of the right or the power of binding and controlling posterity [...] or of commanding for ever how the world shall be governed, or who shall govern it [...] Every age and generation must be as free to act for itself in all cases as the age and generations which preceded it. The vanity and presumption of governing beyond the grave is the most ridiculous and insolent of all tyrannies (Paine, 1791, p. 9).

In a similar vein, William Wordsworth, in Book Ten of The Prelude (1805), recalled his sense that events in France marked the 'dawn' of a new epoch, 'when Reason seemed most to assert her rights', and civil society might at last be free from 'the meagre, stale, forbidding ways/ Of custom, law, and statute' (lines 696-705). British political commentators understood, in short, that the French Revolution was an attempt to restart history, and this became abundantly clear 
when the Revolutionary Convention of the new French Republic devised, in October 1793, as part of a series of cultural reforms designed to remove aristocratic and religious symbolism from public life, a new calendar based on seasonal weather patterns, agricultural practices, and so forth. The attempt was to regenerate human history by bringing it in line with natural history.

Percy Shelley's great verse narratives of successful revolutionary change, Queen Mab (1813) and Prometheus Unbound (1820), describe the arrival of a politically progressive version of what Francis Fukuyama would later describe as 'the end of history': the moment at which civil society achieves its final, definitive form, and the struggle between competing political systems ends (Fukuyama, 1992). ${ }^{7}$ Queen Mab is perhaps the most explicit on this point, looking forward to a 'happy Earth! reality of Heaven!' in which 'Time, the conqueror', once 'the king of earth', has succumbed to the 'sympathies of soul and sense/ That mocked his fury and prepared his fall' (IX 1, 33, 36-7). Shelley's writing often represents human history as a function of natural history, insisting that 'nature and culture are coterminous', as Timothy Morton puts it, 'part of the same phenomenon' (Morton, 2006, pp. 193, 187). Hence, in Shelley's imagining of 'the end of history', the revolutionary regeneration of human culture goes hand in hand with the regeneration of the natural environment, breaking what the Earth, in Prometheus Unbound, recognises as the connection between environmental degradation and 'the polluting dust' of socio-political injustice:

\section{[...] for my wan breast was dry}

With grief; and the thin air, my breath, was stained

With the contagion of a mother's hate

Breathed on her child's destroyer (I, 160, 176-9).

Again, Queen Mab is perhaps the most explicit of the two works on this point, envisaging 'how sweet a scene will earth become/ When man with changeless nature coalescing,/ Will undertake regeneration's work, / When its ungenial poles no longer point/ To the red and baleful sun (VI 39, 43-5). As Shelley explains in his own note to this passage of Queen Mab, he is drawing, here, on the idea proposed by some contemporary astronomers, that a gradual shift in the angle of the earth's axis relative to the sun would produce a benevolent climate across the globe, thereby removing the environmental basis for inequality and the struggle for resources. Both Queen Mab and Prometheus Unbound also envisage dramatic shifts in how humans relate to and consume the environment, including changes in diet and the treatment of animals. ${ }^{8}$ For Shelley, in short, the revolutionary regeneration of civil society, and the consequent end of history, is predicated entirely upon what we might today call sustainability and environmental consciousness.

\section{Doubting Time: History and Natural History}

For all the prima facie confidence which Queen Mab and Prometheus Unbound have in the possibility of the end of history, however, with a rejuvenated humanity inhabiting a rejuvenated world, both works also exhibit doubts about both how, exactly, such an end might be brought to pass, and about how, ultimately, sustainable such an end might be. In the final

\footnotetext{
${ }^{7}$ Shelley's great verse narrative of unsuccessful revolutionary change, Laon \& Cythna (1817), was intended to correct what Shelley rightly diagnosed as the despondency triggered by the collapse of the French Revolution in those had supported it and still felt by those of his own generation who wished to promote progressive political reform.

${ }^{8}$ For Shelley's engagement with various contemporary discourses surrounding diet, animal rights, and politics, see Morton, 1994.
} 
act of Prometheus Unbound, for example, Demogorgon, who embodies the agency of change, offers some startling advice:

Gentless, Virtue, Wisdom, and Endurance:

These are the seals of that most firm assurance

Which bars the pit over Destruction's strength;

And if, with infirm hand, Eternity,

Mother of many acts and hours, should free

The serpent that would clasp her with his length,

These are the spells by which to re-assume

An empire o'er the disentangled Doom (IV, 362-69).

This is succinct as a statement of the gradualist politics which Shelley, drawing on the Enquiry Concerning Political Justice (1793) of his father-in-law William Godwin (1756-1836), made the foundation for his narratives of social transformation in both Queen Mab and Prometheus Unbound. But Demogorgon's advice begs the question of why, if successful political and environmental transformation has been achieved, such a politics might again become necessary: if we have reached the end of history, how or why might historical time once again threaten to break out of, or 'disentangle' a stable eternity?

By hinting at such questions, Shelley is pointing to complex and wide-ranging debates in contemporary natural philosophy about the course of natural history and about the putative relationship between natural history and human history. The theories of population advanced by Thomas Malthus (1766-1834) in his Essay on the Principle of Population (1798) are probably, today, the most familiar of the many attempts in the late eighteenth and early nineteenth centuries to extrapolate links between natural and political history. Malthus argued that natural history was fundamentally incompatible with an egalitarian society - at least for as long as the population continued to grow at a rate which outstripped available resources. In his Philosophical View of Reform (1819), Shelley attacks Malthus's suggestion that the poor should refrain from reproduction as the 'doctrines [...] of a eunuch and a tyrant', but Malthus's wider theory about population and resources was not so easy to dismiss (Shelley, 1954, p. 247). ${ }^{9}$

Neither was contemporary speculation about the geological history of the earth and about the implications which that history might have for human civilisation. The concept of geological 'deep time' - the idea that the earth was immeasurably, perhaps unimaginably older than Biblical and other comparable chronologies implied - had gained considerable traction by Shelley's lifetime. ${ }^{10}$ But debates still ranged about the kinds and the consistency of the geological processes which operated over this immense timespan. For some, such as the two Scotsmen Patrick Brydone (1736-1818) and James Hutton (1726-97), the available evidence pointed towards a linear history, with uniform processes including glaciation and volcanism as the primary agents of geomorphic change. But for others, such as the paleontologists Georges Cuvier (1769-1832) in France and William Buckland (1784-1856) in England, the evidence pointed rather to a geological history made up of recurrent cycles of creation and catastrophic destruction. Cuvier's Théorie de la Terre (1812), translated into English the following year as an Essay on the Theory of the Earth (1813), was the seminal statement of this understanding of geological history during Shelley's lifetime. Lord Byron (1788-1824) made it the basis of the vision experienced by Cain in Act II of his eponymous drama, published in

\footnotetext{
${ }^{9}$ For Shelley's engagement with Malthus, see Pulos, 1952; Scrivener, 1982, pp. 262-6; and Lewis, 2014.

${ }^{10}$ For more on the discovery and representation of 'deep time' in late eighteenth- and early nineteenth-century cultural texts, see Rudwick, 2005 and Duffy, 2013: 72-80.
} 
1821, and Shelley had already alluded to it in Act IV of Prometheus Unbound, where a mysterious 'Orb' makes visible to Ione and Panthea the 'melancholy ruins/ Of cancelled cycles' buried beneath the surface of the earth, which include not only extinct animals but also the remains of former civilisations and even proto-hominids, all 'jammed in the hard, black deep' (11. 269, 288-89, 302).

Prometheus Unbound never really engages the question of why these former cycles were cancelled, but Shelley's mention of former civilisations points to one of the key political applications of Cuvier's theory: what did the ruins of past civilisations imply about the civilisations of the present? In British eighteenth-century ruin sentiment, such questions often took the form of concerns that the fate of Classical Greece and Rome, and of the Roman Empire in particular, might omen badly for the fate of the nascent British Empire. Comfort could often be found in the argument that past civilisations had fallen because of their lack of Christianity and/or their corrupt civic and social life: the History of the Decline and Fall of the Roman Empire (1776-88) compiled by Edward Gibbon (1737-94) is, of course, the best-known example of this view. But it wasn't always easy to confine such questions to civilisations safely distant in the past and works like Cuvier's Theory gave them a new impetus in the second decade of the nineteenth century. Before he had engaged with Cuvier in Cain, for example, Byron had made a political appropriation of Cuvier's catastrophism the centrepiece of the fourth canto of Childe Harold's Pilgrimage (1818), in his celebrated and controversial interpretation of the 'imperial mount' in Rome:

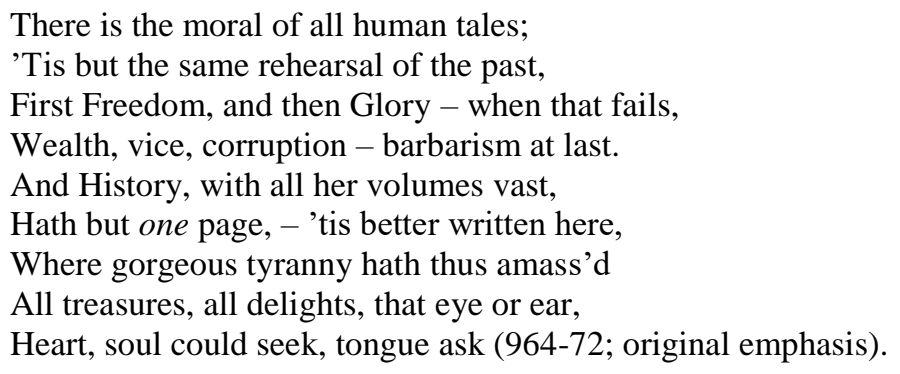

On the face of it, Byron's assessment is based on the ancient history of Rome: first a republic ('Freedom'), then an empire ('glory'), then a period of decline ('vice, corruption') before the final overthrow ('barbarism'). But as Springer (1987) and Duffy (2005) have shown, this ancient history of Rome was mirrored by the sustained and substantial struggle for ideological and cultural and possession of the city during the Revolutionary and Napoleonic Wars. In February 1798, France occupied Rome, abolished the papacy and (re)proclaimed a Roman Republic; this was overthrown two years later and the papacy restored; Napoleon Bonaparte (1769-1821) proclaimed Rome a free imperial city in May 1809 and abolished the papacy for a second time; and following Napoleon's defeat at the Battle of Waterloo (1815), the papacy was once again restored when Austria took possession of Italy. For Byron in Childe Harold, then, the recent history of the city mirrored its ancient history in an unbreakable, Cuvierian cycle of creation and catastrophic destruction.

Shelley, as has been well-documented, reacted angrily to Byron's interpretation of the lessons of history, fearing the despondency which the hugely-anticipated and widely-read fourth canto of Childe Harold's Pilgrimage would spread about the possibility of successful and sustainable political change. In a letter to his friend Thomas Love Peacock (1785-1866) written on 17 or 18 December 1818, Shelley condemns Byron's poem unequivocally: 'the spirit in which it is written', Shelley writes, 'is, if insane, the most wicked \& mischievous insanity that ever was given forth' (Shelley, 1964 2, p. 58). But for all Shelley's anger with Byron, his own narratives of political change are not, as we have seen, entirely confident in developing a linear, teleological model of historical time moving towards a regenerated 'end 
of history' which cannot be undone. We have already considered Demogorgon's puzzling advice at the end of Prometheus Unbound. As further evidence of such doubts, we can add the final chorus of Shelley's last verse narrative of political change, Hellas, a Lyrical Drama (1821), which dramatises the ongoing Greek revolution against the Ottoman Empire, and which likewise raises the spectre of political history as an endless Cuvierian cycle of creation and destruction:

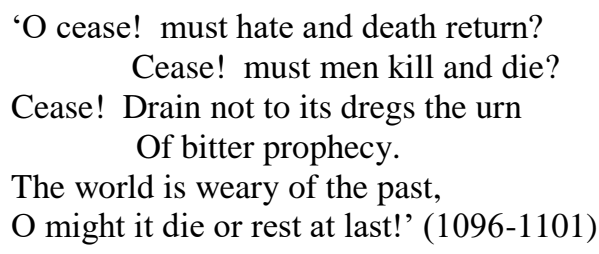

Such cyclical understandings of political history have, of course, a long heritage in European thought, stretching back at least as far as the Classical Greek concept of anacyclosis, the most influential expression of which in the Histories of Polybius (c. 208 - c. 125 BC) Shelley (and Byron) knew well. ${ }^{11}$ Following the work of Malthus and Cuvier, however, it became possible to argue - or to fear - that such cyclical histories of political creation and collapse were natural: as inevitable and inescapable as the geological processes of which they could be said to be the analogues.

This is the problem of historical time which Shelley's political verse never manages altogether satisfactorily to resolve. And it is a version, of course, of the problem which we have seen Shelley struggling and failing to resolve in his late, intensely personal lyrics: how to reach the end of history; how to stop the clock and remain 'content' in 'the present moment', as Shelley put it in his letter to John Gisborne of 18 June 1822. In Shelley's last major work, the unfinished 'The Triumph of Life', lyrical and historical time blend as Shelley once again takes up and seeks to redress the problem of loss in time, and it is to that poem that I want to turn in closing.

\section{'The World and its Mysterious Doom'}

Shelley began work on 'The Triumph of Life' in late May 1822. As noted, and has been well-documented, the unfinished draft has significant stylistic, intertextual and (apparently) conceptual debts to the Divina Comedia of Dante and the Trionfi of Petrarch. In addition to his use of the terza rima verse form pioneered by both works, Shelley adapts from Dante the idea of a guide leading the speaker through hell and purgatory towards salvation. In Shelley's case, the guide is Jean-Jacques Rousseau (1712-88) and the inferno is the recent history of the Revolutionary and Napoleonic Wars, what Shelley in his draft calls 'the times that were/ And scarce have ceased to be' (11. 233-4). Rousseau, recognised in Shelley's day as one of the major intellectual architects of the French Revolution through works like Discourse on Inequality (1754), The Social Contract (1762) and Julie, or the New Heloise (1761), is thus an appropriate choice. 'If I have been extinguished', he tells Shelley's narrator, 'yet there rise/ A thousand beacons from the spark I bore' (11. 206-7), and, later: 'I/ Am one of those who created, even/ If it be but a world of agony (11. 294-5). Shelley's draft of 'The Triumph of Life' breaks off without any conclusion in sight, but comparison with the structure of Divina Commedia and Petrarch's Trionfi at least raises the possibility that Shelley had a positive conclusion to the journey in mind.

For all its debts to Italian Renaissance writing, however, the extant draft of 'The Triumph of Life' also has much in common with what Abrams describes as the Greater Roman-

${ }^{11}$ Shelley ordered the works of Polybius in December 1812 (see Shelley, 1964 1: 344). 
tic Lyric. The poem opens with a speaker - recognisably a type of Shelley himself - contemplating the Italian landscape from 'beneath the hoary stem/ Which an old chestnut flung athwart the steep/ Of a green Appenine' (11. 24-6). This speaker has been 'kept as wakeful as the stars' by 'thoughts which must remain untold' (11. 21-2). We might reasonably expect the remainder of the draft to involve the working through, in lyric time, of these 'thoughts', but neither what they are nor why 'they must remain untold' is ever again addressed in the extant draft. Instead, 'The Triumph of Life' moves from this ostensibly private beginning towards a much more public reflection on the course of historical events. In other words, it moves, we might say, from lyric time to historical time. The speaker has a vision in which he sees a 'triumphal pageant' where a mysterious figure, later identified by Rousseau as 'Life', drags in chains behind its triumphal chariot major historical figures from Classical to modern times: 'The great, the unforgotten, they who wore/ Mitres and helms and crowns, or wreathes of light,/ Signs of thought's empire over thought' (11. 118, 181, 209-11).

The central problem of 'The Triumph of Life', then, is what lesson should be drawn from the fate of these remembered individuals and from the analogous fates of all the other unremembered dead, whom the speaker compares to 'the million leaves of summer's bier' (1. 51). Or, in other words, what is the nature of historical time and can an 'end of history' be foreseen? The speaker evidently wishes to understand history as a developmental teleology in which the past can be transcended. 'The world and its mysterious doom', he says to Rousseau, 'is not so much more glorious than it was/ That I desire to worship those who drew/ New figures on its false and fragile glass,/ As the old faded' (11. 244-48). But Rousseau resolutely refuses to allow such an optimistic, linear model, advocating instead a cyclical pattern which recalls Cuvier and Byron's account of the 'one page' of history, the old conceptual antagonists of Shelley's Prometheus Unbound and Hellas. 'Figures ever new/ Rise on the bubble', Rousseau replies, 'paint them how you may;/ We have but thrown, as those before us threw,/ Our shadows on it as it past away' (11. 248-51).

From this very public discourse of historical time, Shelley's draft of 'The Triumph of Life' then shifts back to the more private temporality of the lyric as Rousseau, in response to the speaker's questions about his fate, explains how he himself fell victim to 'Life'. Rousseau's answer obviously rebukes even as it seems to confirm Burke's claim in his 'Letter to a Member of the National Assembly' (1791) that the author of the Confessions (1782) 'entertained no principle either to influence his heart, or to guide his understanding, than vanity' (Burke, 1791b, p. 33; original emphasis). 'I was overcome/ By my own heart alone', Rousseau tells Shelley's speaker, 'which neither age/ Nor tears nor infamy nor now the tomb/ Could temper to its object' (11. 240-3). Rousseau then describes a vision which he experienced and which he cites as an explanation of his fate. His account occupies roughly the second half of the extant draft of 'The Triumph of Life'. He describes waking in a beautiful Edenic landscape, where a Lethean river effaces any feeling of loss (and, by extension, of time), filling 'the grove':

With sound which all who hear must needs forget

All pleasure and all pain, all hate and love,

Which they had known before that hour of rest:

A sleeping mother then would dream not of

The only child who died upon her breast

At eventide, a king would mourn no more 
The crown of which his brow was dispossest (11. 317-24).

The arrestation of lyrical (the 'mother') and historical (the 'king') time which Rousseau registers here soon comes to an end, however. ${ }^{12} \mathrm{He}$ encounters what he describes as 'a shape all light' carrying 'a chrystal glass' (11. 352, 358). When Rousseau asks this 'shape' to explain the nature of time - 'shew whence I came, and where I am, and why/ Pass not away upon the passing stream' - she offers him her cup: "'Arise and quench thy thirst' was her reply" (11. 398, 400). Once Rousseau drinks, he is transported instantly from the Edenic scene and finds himself caught up in the 'triumphal pageant' which the speaker witnesses at the start of his vision. Rousseau is transported, that is to say, into a historical time conceived as a process of loss: his vision of the 'Shape all light' is now doubly reduced to 'the ghost of a forgotten form of sleep,/ A light from Heaven whose half-extinguished beam/ Through the sick day in which we wake to weep/ Glimmers, forever sought, forever lost' (11. 428-31). ${ }^{13}$

Shelley's draft breaks off before Rousseau can offer any answers to the speaker's next request that he might interpret this traumatic experience. But a number of conclusions seem possible on the basis of the extant text. Rousseau's account of his experience certainly bears comparison with the structure of the Greater Romantic Lyric, which, we recall, begins with a speaker contemplating a landscape before having some transformative insight. Except that in the case of Shelley's Rousseau, what is experienced is loss and no compensatory, Wordsworthian insight is gained. Also worthy of note is the extent to which the experience described by Rousseau is strikingly similar to the experience described by the speaker himself: both encounter a mysterious figure within a vision which occurs whilst contemplating an Edenic landscape. It is possible to suggest, then, that Shelley's engagement with the traumas of historical and personal time in 'The Triumph of Life' takes the form of a lyric within a lyric, with neither speaker able to reach the resolution which Abrams identifies as the goal of the genre - although in this case, that is because Shelley did not finish the poem.

But would Shelley have been able to resolve the problem of time and narrate such a resolution for Rousseau or for the speaker had he lived to finish 'The Triumph of Life'? The draft breaks down, as I have said, at the same moment as much of Shelley's other lyrical writing from the last six months of his life - poems in which he engages a lot more explicitly with those personal traumas which, we might well suspect, lie behind the 'thoughts' which the speaker of 'The Triumph of Life' tells us 'must remain untold'. However, Shelley's extant draft of 'The Triumph of Life' also poses more troubling questions about the passage of time than merely configuring it as a process of irredeemable loss, and effectively returns us to the doubts about an 'end of history' that we saw at the heart of Prometheus Unbound and Hellas. The consequence of the lyric-within-a-lyric structure is that the mirroring of Rousseau's experience in the speaker's experience suggests exactly the kind of temporal cyclicality that Rousseau perceives and that the speaker seeks to reject. Has the speaker himself been defeated by 'Life' at the moment he encounters Rousseau within his vision just as Rousseau, before him, had been defeated by his encounter with the 'Shape all light' in his vision?

We simply cannot know, now, how Shelley might have tried to resolve the problem of personal and historical time in 'The Triumph of Life' - unless, of course, someone discovers some lost lines of the poem. Having heard Rousseau's story, the speaker asks him 'what is Life?' (1. 544). Shelley's draft then breaks off in mid line as Rousseau begins to answer: 'Happy those for whom the fold/ Of' (11. 547-8). Rousseau's final words certainly bear com-

\footnotetext{
${ }^{12}$ The image of the infant dead on the mother's breast might recall the death of Percy and Mary Shelley's oneyear-old daughter Clara, who died on the evening of 24 September 1818, shortly after they had arrived in Venice.

${ }^{13}$ Rousseau echoes Caliban's lament for his dream in The Tempest III ii 148-51.
} 
parison, however, with the equally-unresolved conclusion of Shelley's last lyric, 'Lines Written in the Bay of Lerici', which takes its point of departure in an evening Shelley spent on the beach in the company of Jane Williams. Like the narrator of 'The Triumph of Life', the speaker of 'Lines Written in the Bay of Lerici' also has secret thoughts which 'must remain untold'. After the speaker has been left alone by the unidentified 'She' whose 'presence and made weak and tame/ All passions' he confesses that 'I dare not/ Speak my thoughts' (11. 1, 27-8, 35-6). Exactly what he dares not speak, however, we can guess from the final lines of the extant draft, in which he tries to evaluate the relationship between 'pleasure', 'regret' and 'forgetfulness':

\footnotetext{
Too happy they, whose pleasure sought

Extinguishes all sense and thought

Of the regret that pleasure [

Seeking life alone, not peace (11. 54-8).
}

This text, like all texts of the poem's final movement, is a conjectural reconstruction - nor can we even be sure that Shelley meant these to be the final lines of the poem. Line 57 is incomplete in Shelley's draft in Bodleian MS. Shelley adds. c. 4, and 'Seeking', in line 58, is only a possible replacement for his first choice, 'Destroying', which he has struck through; 'not peace' is highlighted by underlining and 'alone' inserted above the line. Shelley was not able, before his death, to work out in this intensely personal lyric, the relationship between pleasure, regret, forgetting, life, and peace.

For his part, Rousseau, in 'The Triumph of Life', dwells, as we have seen, on the possibility of forgetting. After he describes how a grieving mother and a deposed monarch would forget their losses in the beautiful valley where he encountered the 'Shape all light', Rousseau assures the speaker that he, too, 'wouldst forget thus vainly to deplore/ Ills, which if ills, can find no cure from thee' (11. 327-8). On the face of it, the 'ills' of which Rousseau speaks are the speaker's earlier lament about the disastrous implications of recent history:

And much I grieved to think how power and will

In opposition rule our mortal day -

And why God made irreconcilable

Good and the means of good (11. 228-31).

In addition to this reference to historical trauma, however, there is also an acknowledgment of personal trauma: Rousseau seems also to intuit, in a kind of fourth-wall break, those 'thoughts' which the narrator has told the reader, but not Rousseau, 'must remain untold'.

Perhaps an easy solution to the problem of loss in time, personal or historical, would be, simply, to forget, to be numbered amongst those whom Rousseau, in 'The Triumph of Life', describes half-wistfully as 'the sleepers in the oblivious valley' (539). Or perhaps this would amount to defeat by 'Life'. Or perhaps, in the end, such a Lethean sleep would simply not be possible, even if it were desirable, because the human experience of time is defined by loss. 'Such things the heart can feel and learn, but not forget.'

\footnotetext{
${ }^{14}$ Shelley, 'To Constantia' (1817), 1. 44.
} 


\section{References}

Abrams, M. H. (1965). Structure and style in the greater romantic lyric. In F. W. Hills and H. Bloom (Eds.), From sensibility to romanticism: essays presented to Frederick A. Pottle, 527-560. Oxford: Oxford University Press.

Burke, E. (1791a). Reflections on the Revolution in France. Dublin.

Burke, E. (1791b). Letter to a Member of the National Assembly. London: Dodsley.

Byron, G. G. (1986), Lord. A critical edition of the major works. J. J. McGann (Ed.): Oxford: Oxford University Press.

Cuvier, G. (1813). Essay on the theory of the earth. (R. Kerr Trans.). Edinburgh: Blackwood.

Duffy, C. (2015). Percy Shelley's 'Unfinished Drama' and the problem of the Jane Williams poems. European Romantic Review, 26(5), 615-632.

Duffy, C. (2013). The landscapes of the sublime, 1700-1830: 'classic ground'. London: Palgrave.

Duffy, C. (2006). Shelley and the revolutionary sublime. Cambridge: Cambridge University Press.

Fukuyama, F. (1992). The end of history and the last man. New York: Free Press.

Gibbon, E. (1788). The history of the decline and fall of the Roman empire. London. Strahan \& Cahell.

Godwin, W. (1793). Enquiry concerning political justice and its influence on morals and happiness. London: Robinson.

Goethe, J. W. Von. (1808). Faust: Eine Tragödie. Erste Teil. Tubingen: Kollen.

Lewis, D. (2014). Shelley's critique of Malthus in 'A Defence of Poetry'. European Romantic Review, 25(5), 575-590.

Malthus, T. (1798). Essay on the principle of population. London: Johnson.

Matthews, G. (1962). On Shelley's 'The Triumph of Life'. Studia Neophilologica, 34, 104134.

Matthews, G. (1961). Shelley and Jane Williams. Review of English Studies, 45, 40-48.

Morton, T. (2006). Nature and culture. In T. Morton (Ed.). The Cambridge Companion to Shelley, 185-207. Cambridge: Cambridge University Press.

Morton, T. (1994). Shelley and the revolution in taste. Cambridge: Cambridge University Press.

Paine, T. (1791). The rights of man. London: Jordan.

Pulos, C. E. (1952). Shelley and Malthus. PMLA, 67(2), 113-124,

Reiman, D. (1965). Shelley's 'The Triumph of Life': a critical study. Urbana: University of Illinois Press.

Reiman, D. (1963). Shelley's 'The Triumph of Life': the biographical problem. PMLA, 78, 536-550.

Rudwick, M. (2005). Bursting the limits of time: the reconstruction of geohistory in the age of revolution. Chicago. University of Chicago Press.

Scrivener, M. H. (1982). Radical Shelley. New York: De Gruyter. 
Shelley, P. B. (2017). Percy Bysshe Shelley: selected poems and prose. J. Donovan and C. Duffy (Eds.). London: Penguin.

Shelley, P. B. (1964). The letters of Percy Bysshe Shelley. 2 volumes. F. L. Jones (Ed.). Oxford: Clarendon.

Shelley, P. B. (1954). Shelley's prose. D. L. Clark (Ed.). Albuquerque: University of New Mexico Press.

Springer, C. (1987). The marble wilderness: ruins and representation in Italian romanticism, 1775-1850. Cambridge: Cambridge University Press.

Wordsworth, W. (2008). William Wordsworth: the major works. S. Gill (Ed.). Oxford World's Classics: Oxford. 